\title{
DIGITALCOMMONS
}

@WAYNESTATE —

Wayne State University

Law Faculty Research Publications

Law School

$1-1-2014$

\section{A New Crime for Corporate Misconduct?}

Peter J. Henning

Wayne State University, peter.henning@wayne.edu

\section{Recommended Citation}

Peter J. Henning, A New Crime for Corporate Misconduct?, 94 Miss. L.J. 43 (2014).

Available at: https://digitalcommons.wayne.edu/lawfrp/250

This Article is brought to you for free and open access by the Law School at DigitalCommons@WayneState. It has been accepted for inclusion in Law Faculty Research Publications by an authorized administrator of DigitalCommons@WayneState. 


\title{
A NEW CRIME FOR CORPORATE MISCONDUCT?
}

\author{
Peter J. Henning*
}

INTRODUCTION

I. CRIMINAL LIABILITY OF CORPORATE EXECU'TIVES ..............50

A. Responsible Corporate Officer Doctrine.

$B$. Should Responsible Corporate Officer Liability Be Applied More Broadly? ............................................59

II. GERMANY'S ABUSE OF TRUST STATUTE ...........................64

III. BRITAIN'S RECKLESS BANKER LAW ..................................76

IV. CONSTRUCTING A NEW CRIME FOR CORPORATE MISCONDUCT.

"And if you have not been faithful in the use of that which is another's, who will give you that which is your own?"

Luke 16:12 (New American Standard Bible)

\section{INTRODUCTION}

If one accepts the statistics offered by the federal government about its response to perceived misconduct leading to the financial crisis in 2008, the ready conclusion seems to be that most perpetrators have been held accountable. For example, the Financial Fraud Enforcement Task Force, which was created in 2009 to pursue cases related to the crisis, routinely takes credit for almost any prosecution involving financial misconduct, touting that "[o]ver the past three fiscal years, the Justice Department

- Professor of Law, Wayne State University Law School. I appreciate the comments and suggestions of my colleagues on the Wayne State University Law School faculty who allowed me to inflict a draft on them, for the gracious comments provided by Professor Brandon Garrett (Virginia) and Dr. Marc Engelhart (Max-Planck-Institut für ausländisches und internationales Strafrecht), and the research assistance of Pamela Wall (Wayne State University Law School Class of 2015). 
has filed nearly 10,000 financial fraud cases against nearly 15,000 defendants including more than 2,900 mortgage fraud defendants." 1 The Securities and Exchange Commission (SEC) has a tally of the civil enforcement actions it has brought for violations arising from the financial crisis, claiming that 175 companies and individuals have been charged, including 70 senior corporate officers, resulting in more than $\$ 1.87$ billion of penalties agreed to or ordered. ${ }^{2}$ Interestingly, the Department of Justice was also caught inflating its claims about the number of prosecutions brought in 2012 related to its "Distressed Homeowner Initiative," which it claimed was "inadvertent $\left[.{ }^{3}\right.$ In an addendum to its press release regarding a prosecution, the Department rescinded its previous figure and significantly decreased the reported number of defendants charged. ${ }^{4}$

Yet, there is clearly a disconnect between what the government claims has been a successful enforcement effort, targeting crimes and civil violations that arose during the run-up to the financial crisis, and the public's perception that the Department of Justice and SEC have failed to hold senior management accountable for the economic calamities inflicted. In 2013, PBS produced an investigatory documentary called "The Untouchables"-so entitled for Wall Street's apparent immunity from the long arm of the law-which featured an interview with then-Assistant Attorney General Lanny A. Breuer, who led the Criminal Division at the Department of Justice from 2009 until 2013 , about the apparent lack of prosecutions from the financial crisis:

LANNY BREUER: Well, first of all, I think that the financial crisis, Martin, is multi-faceted. And what we've had is a

I Press Release, U.S. Dep't of Justice, Three Former UBS Executives Sentenced to Serve Time in Prison for Frauds Involving Contracts Related to the Investment of Municipal Bond Proceeds (July 24, 2013), available at http://www.stopfraud.gov/iso/opa/stopfraud/2013/13-at-839.html.

2 SEC Enforcement Actions: Addressing Misconduct That Led to or Arose from the Finartial Crisis, U.S. SEC. \& EXCH. COMM'N, https/www.sec.gow/spotlight/enf-actionsfo.shtml (last updated Sept. 11, 2014).

3 See Press Release, U.S. Dep't of Justice, Financial Fraud Enforcement Task Force Members Reveal Results of Distressed Homeowner Initiative (revised Aug. 9, 2013), ouailable at http:/www.justice.gov/opa/pr/2012/October/12-ag-1216.html.

4 Id. 
multi-pronged, multi-faceted response. And it's simply a fiction to say that where crimes were committed, we didn't pursue the cases. And that's why, where crimes were committed, you have more people in jail today for securities fraud, bank fraud and the like than ever before.

MARTIN SMITH: But no Wall Street executives.

\section{LANNY BREUER: No Wall Street executives. 5}

Former Senator Ted Kaufman lays the blame for the lack of prosecutions of financial executives squarely at the door of the Department of Justice, stating "that those most responsible for indicting and prosecuting Wall Street executives seem to believe that, just as there are banks that are too big to fail, there are people who are too big to jail."' Jeff Connaughton, who served as chief of staff for Senator Kaufman, goes a step further and asserts that "[f]rom the beginning, Ted and I feared that the Obama administration leadership might tend to let Wall Street off the hook so as not to impede the economic recovery."7

Judge Jed S. Rakoff of the United States District Court for the Southern District of New York, a federal prosecutor and defense lawyer prior to his appointment to the bench, stated that in his view "the Department of Justice has never taken the position that all the top executives involved in the events leading up to the financial crisis were innocent; rather, it has offered one or another excuse for not criminally prosecuting them-excuses that, on inspection, appear unconvincing." 8 A former SEC aitorney, in a speech at his retirement party in March 2014, lamented that the agency's "best and brightest" left because they saw that it "polices the broken windows on the street level and rarely goes to the penthouse floors" so that "[t]ough enforcement-

n PBS Fronline: The Untouchables (PBS television broadcast Jan. 22, 2013), available at http:/www.pbs.org/wgbh/pages/frontline/business-economy-financialerisishuntouchables/transeript-37/ (providing a transcript of the broadeast).

- Ted Kaufman, Why DOJ Deemed Bank Execs Too Big To Jail, ForBES (July 29, 2013, 9:30 AM), http:/www forbes.com/sites/tedkaufman/2013/07/29/why-doj-deemedbank-execs-too-big-to-jaill.

7 JefF ConnaUghton, The PAYOli: Why WaLl StReft AlWays WiNs 65 (2012).

a Jed S. Rakoff, The Financial Crisis: Why Have No High-Level Executives Been Prosecuted?, N.Y. REV. Books (Jan. 9, 2014), http:/www.nybooks.com/articles/ archives/2014/jan/09/financial-crisis-wby-no-executive-prosecutions/. 
risky enforcement-is subject to extensive negotiation and weakening." 9

One important reason proffered for the lack of prosecutions of financial executives in the United States has been the difficulty of proving the violation of criminal laws typically used to prosecute corporate misconduct, such as mail and wire fraud, securities fraud and filing false statements with the government. These offenses require establishing a defendant's specific intent to commit the crime, ${ }^{10}$ a seemingly insurmountable standard of proof for cases related to the financial crisis. In "The Untouchables" documentary, an associate deputy director of the Federal Bureau of Investigation said that prosecutions for the packaging of toxic mortgages were not pursued because "[w]e were not able to show criminal intent sufficiently enough to obtain what we believe-to obtain a conviction of a criminal[.]" 11 Preet Bharara, the United States Attorney for the Southern District of New York who was pictured on the cover of Time magazine behind the headline "This Man Is Busting Wall Street," 12 had this to say about the difficulty in pursing cases for allegedly false statements made to the government:

Maybe there's a lot of smoke-now comes the proof. This guy's going to testify, 'My accountant's a smart guy-I just relied on my accountant.' The accountant's going to say, 'I just relied on what he gave me,' and everyone has plausible deniability. That's a simple example of a way in which people can get

9 Robert Schmidt, SEC Goldman Lawyer Says Agency Too Timid on Wall Street Misdeeds, BLOOMBERG (Apr. 8, 2014), http://www.bloomberg.com/news/2014-04-08/secgoldman-lawyer-says-agency-too-timid-on-wall-street-misdeeds.html; see also James Kidney, Retirement Remarks (Mar. 27, 2014) (transcript on file with author), available at https://www.documentcloud.org/documents/1105575-s.e.c-officials-retiremenspeech. html.

10 See United States v. Wynn, 684 F.3d 473, 478 (4th Cir. 2012) ("TThe mail fraud and wire fraud statutes have as an element the specific intent to deprive one of something of value through a misrepresentation or ather similar dishonest method, which indeed would cause him harm."); United States $v$. Brooks, 681 F.3d 678, 700 (5th Cir. 2012) ("Violation of the wire-fraud statute requires the specific intent to defraud. . . .).

"PBS Frantline: The Untouchables, supra note 5.

12 This Man Is Busting Wall St.: Prosecutor Preet Bharara Collars the Masters of the Meltdown, TIME, Feb. 13, 2012, at cover, aucilable at http://content.time.com/time/covers/0,16641,20120213,00.html. 
away with even criminal activity when they're making false certifications to the government. ${ }^{3}$

If a primary reason for the lack of prosecutions of executives is the high threshold for proving intent, then one potential response-which has not been expressed by the Department of Justice to this point-may be to reduce the requisite intent element, so that it is easier to pursue a case and establish a violation when there are substantial losses from corporate decisions. Reducing the threshold for liability to one of recklessness-or even negligence-would facilitate the government's use of the criminal law to police corporate management. Defining a new crime that can be established by a lower level of intent could lead to more prosecutions of corporate management whose decisions can have a wide economic impact. It would be a deterrent to those executives contemplating a course of action involving outsized risks that might otherwise be pursued when there is no realistic threat of individual criminal liability.

Whether a lower burden of proof, designed to increase the number of prosecutions of corporate executives, is a good thing represents a different issue entirely. A range of commentators have bemoaned the expansion of the federal criminal law, the usual venue for pursuing cases involving large-scale corporate misconduct, as part of a broader critique known as "overcriminalization."14 Usually described in ominous terms, the notion is that there are too many prosecutions and there is too much use of criminal sanctions in American society when civil or administrative remedies can achieve the same results. Particular targets of this critique are Congress and the Department of Justice, often assailed as running roughshod over the states in a stampede to pursue conduct traditionally reserved to local

13 George Packer, A Dirty Business, New Yolken, June 27, 2011, http:/www.newyorker.com/magazind/2011/06/27/a-dirty-business.

14 See, e.g., Bryan H. Druzin \& Jossica Li, The Criminalization of Lying: Under What Circumstances, If Any, Should Lies Be Made Criminal?, 101 J. CRIM. L. \& CRIMINOLOGY 529, 553 (2011) (There is broad agreement in the legal community that the justice system is already severely ovororiminalized."). See generally Sanford H. Kadish, The Crisis of Dvercriminalization, 374 ANNALs AM. ACAD. POL. \& SOC. SCJ. 157 (1967) (discussing "problems of overcriminalization"). 
prosecutors. ${ }^{15}$ Aspects of this critique are certainly open to question, and it has been pointed out that "[m]any of the statutes that have historically generated controversy because of their triviality (for example, the prohibition on using the likeness of Smokey Bear) or federalism concerns (such as the federal carjacking statute) are rarely, if ever, used." 16 Given the persistent complaints about the lack of prosecutions from the financial crisis, there is an interesting question of whether the overcriminalization concerns may need to give way to allow one more federal statute that can be used against corporate executives involved in conduct that results in significant harms to their company and the broader economy. ${ }^{17}$

There are examples outside the United States that can guide an effort to add to the federal arsenal to pursue cases in the future for the type of conduct that resulted in so much economic disruption in 2008. One approach adopted in the United Kingdom makes it a crime for executives to engage in reckless conduct that causes a bank to fail. The initial proposal for the legislation drew the support of Prime Minister David Cameron for "criminal penalties against bankers who behave irresponsibly." 18 In

15 See Peter J. Henning, Making Sure "The Buck Stops Here": Barring Executives for Corporate Violations, 2012 U. CHI. LEGAL F. 91, 107-08 ("The critique that there is overcriminalization appears to be used more as a placeholder to describe how the criminal law has expanded so that there are too many defendants being prosecuted and incarcerated, sometimes for significant periods of time.").

16 Susan R. Klein \& Ingrid B. Grabey, Debunking Claims of Over-Federalization of Criminal Law, 62 EMORY L.J. 1, 5-6 (2012).

17 Even if one accepts the premise that the law should be changed to permit more prosecutions of executives for their business decisions, there is the additional concern about whether the criminal law is the best way to police corporate conduct. At least when the company is the target of the prosecution, Professors Fischel and Sykes have concluded that while "there are cases where government fines and penalties make sense, the civil liability system is better suited to calculate appropriate fines and penalties for organizational defendants." Daniel R. Fischel \& Alan O. Sykes, Corporate Crime, 25 J. LEGAL STUD. 319, 321 (1996). The threat of imprisonment is a powerful tool to be used for ordinary business conduct, and it may be that civil liability rather than prison is the best way to deal with corporate decisions, especially those made in diffuse organization in which a number of different individuals have input. For the purposes of this Essay, I will accept that there is a need for a new law, and that the criminal sanction can be applied appropriately to business decisions by corporate executives while acknowledging that there are good arguments against even pursuing new legislation.

Is Matt Chorley \& Ruth Sutherland, 'We WILL Jail Reckless Bankers': Cameron Vous to Criminalise Irresponsible Behaviour and Ban Bonuses at Bailed Out Banks, 
Germany, Christian Wulff said in 2009 when he was premier of Lower-Saxony that "[b]lowing a bank's money contrary to managers' duties is a criminal offence" 19 in reference to a provision of the German criminal code that makes it a crime for corporate management to engage in conduct that is an abuse of trust. That provision focuses on the failure to safeguard a company's property and could be a means to prosecute executives for taking excessive risks that result in substantial economic harm.

Federal law in the United States is not completely bereft of tools that could be adapted to the corporate setting so as to permit prosecutions for risky management decisions like those identified as significant contributors to the financial crisis. For example, in the environmental and food and drug safety fields, the "responsible corporate officer" doctrine permits a prosecution without regard to the defendant's knowledge or intent for the underlying violation, relying instead on the person's supervisory role as the basis for imposing criminal liability. ${ }^{20}$ At one time, there was a provision of federal law that might have been useful to address misconduct that involved dishonesty by senior management. The federal "right of honest services" statute, 18 U.S.C. $\S 1346$, provided that one type of fraud subject to prosecution involved "a scheme or artifice to deprive another of the intangible right of honest services." 21 This was interpreted by some lower courts to prohibit conflicts of interest and self-dealing that resulted in illicit gains to the defendant, even if there was no direct harm to the party owed the honest services. But the Supreme Court eliminated that analysis in 2010 in Skilling $u$. United Stales when it held that $\$ 1346$ was limited to conduct in

DAILY MAIL (June 19, 2013, 10:33 AM), http:/www.dailymail.co.uk/nows/article. 234451.1/David-Cameron-We-WITL-jajl-reckless-bankers.html.

$1 \%$ Volker Krey, Financial Crisis and German Criminal Law: Managers' Responsibility for Highly-Speculative Trading in Obscure Asset-Backed Sectrities Based on American Subprime Mortgages, 11 GERMAN L.J. 319, 320 (2010).

so The Supreme Court recognized this doctrine in United States v. Park, 421 U.S. 658, 676 (1975), where it permitted "conviction of responsible corporate officials who, in light of this standard of care, have the power to prevent or correct violations."

21 18 U.S.C. \& 1346 (2012). 
which the defendant receives a bribe or kickbacks, the type of financial misconduct rarely seen in the executive suite. ${ }^{22}$

A concerted effort to subject corporate executives to the threat of criminal prosecution for their mismanagement of a company would require a new law that can effectively reach conduct without requiring proof of an intent to defraud or to engage in purposeful misconduct-the stumbling blocks the Department of Justice identified for not prosecuting cases from the financial crisis. In this Essay, I will look at possible approaches to adopting a statute that would permit federal prosecutors to pursue cases against corporate executives for their managerial decisions-decisions that result in significant economic harms, like those seen in the 2008 financial crisis. Part I will review different federal laws that already target managers under the "responsible corporate officer" doctrine-laws that do not require proof of specific intent and in some instances hold a defendant strictly liable-and discuss the problems that arise when adapting that approach to the broader corporate setting. Parts II and III will examine the strengths and weaknesses of German and British statutes that target corporate and bank management and consider how they provide guidance for possibly enacting a new crime in the United States. The Essay concludes by considering whether new legislation is needed, or whether the conduct that led to the financial crisis was sui generis and does not support a call for enacting a new crime.

\section{CRIMINAL LIABILITY OF CORPORATE EXECU'TIVES}

The challenge of establishing a defendant's intent is a familiar one in the criminal law. Courts recognize that proving what is in an individual's mind does not depend solely on what the person says he or she was thinking at the time and circumstantial evidence can suffice for a jury to infer the requisite intent even if the defendant denies involvement in the offense. For example, in United States v. Lamarre, ${ }^{23}$ a bank fraud prosecution, the Seventh Circuit said that "[s]pecific intent may be established by circumstantial evidence and inferences drawn from the scheme

22 Skilling v. United States, 561 U.S. 358, 411-12 (2010).
23 248 F.3d 642 (7th Cir. 2001). 
itself," so that "actions such as knowingly depositing an NSF or forged check, knowingly writing checks on an inadequate account balance, and providing false information on loan documents constitute circumstantial evidence of specific intent to defraud."24 When knowledge is an element of the offense, the government can request what is commonly known as the "ostrich instruction," which permits the prosecution to introduce evidence of a defendant's conscious avoidance of the very information that would have shown criminal conduct, thus proving that the person acted knowingly by being deliberately ignorant. ${ }^{25}$

In prosecutions of corporate misconduct, however, even those more forgiving standards have often proved to be too great an impediment to establishing criminal intent for senior management. Many corporate officials are far removed from the day-to-day company decisions that can turn out to be fraudulent, so it is difficult to find evidence to establish their knowledge in the circumstantial evidence. For example, the former Chairman and CEO of Lehman Brothers denied any awareness of an accounting gimmick that ultimately involved transactions running into the billions of dollars. ${ }^{26}$ Those borrowings made the firm appear to investors to be much stronger in the months before its bankruptcy in September 2008 than it actually was. This claim of ignorance appears to have succeeded, because neither the Department of

24 Id. at 649 .

25 See United States v. Boone, 628 F.3d 927, 935-36 (7th Cir. 2010) ("Recognizing that Boone's defense was in part to deny his knowledge of the scheme, the district court provided the ostrich instruction to the jury, instructing them that: "When the word "knowingly" is used in these instructions, it means that the defendant realized what he was doing and was aware of the nature of his conduct and did not act through ignorance, mistake or accident. Knowledge may be proved by the defendant's conduct. and by all the facts and circumstances surrounding the case. You may infer knowledge from a combination of suspicion and indifference to the truth. If you find that a persan had a strong suspicion that things were not what they seemed or that someone had withbeld some important facts, yet shut his eyes for fear of what he would learn, you may conclude that he acted knowingly, as I have used that word. You may not conclude that the defendant had knowledge if he was merely negligent in not discovoring the truth." ).

26 See Public Policy Issues Raised by the Report of the Lehman Bankruplcy Examiner: Hearing Before the H. Comm. on Fin. Serus., 111th Cong. 70 (2010) (statement of Richard S. Fuld $\mathrm{Jr}_{+}$Farmer Chairman and CEO, Lehman Bros) ("Let me start by saying that $I$ have absolutely no recollection whatsoever of hearing anything about or seeing documents related to Repo 105 transactions while I was the CEO of Lehman."). 
Justice nor the SEC pursued a case against any of its executives. ${ }^{27}$ In another case, the SEC accused the owner of a hedge fund, Steven A. Cohen, of failing to supervise portfolio managers and analysts at the firm who engaged in insider trading. ${ }^{28} \mathrm{Mr}$. Cohen denied reviewing an e-mail he received that raised questions about the source of the information the firm used for its trades, claiming he only had time to look at a few of the many communications received every day. ${ }^{29}$ Unlike defendants who brandish weapons or traffic narcotics and stolen property, whose denials of culpability are inherently suspect, a corporate manager can plausibly claim to have been ignorant of the details of a transaction, to not understand the full ramifications of what happened, or to have believed that there was nothing improper about a decision because other advisers-both inside and outside the company-never questioned its propriety. Ignorance of the law may not be an excuse for a crime, but it can be an effective defense when the violation requires proof of knowledge.

One criminal statute directed squarely at corporate executives is the financial certification provision of the SarbanesOxley Act, adopted by Congress in response to the accounting frauds that felled companies like Enron, WorldCom, and Adelphia Communications. The statute imposes significant criminal penalties on the chief executive officer and chief financial officer who knowingly and willfully certify the financial statements, which do not comport with the accounting rules, of a company whose shares are publicly traded, with a lower penalty for such a

37 See Henning, supra note 15 , at 118 ("A bankruptcy examiner concluded that the Repo 105 trades were potentially misleading to investors, but Richard $\mathrm{S}$. Fuld Jr, the firm's former CEO, proclaimed his ignorance of the entire set of financial machinations, asserting that he relied on others to deal with such things. Neither the DOJ nor the SEC has filed charges against any former Lehman officers for the Repo 105 transactions-or anything else for that matter-and the firm's bankruptcy means the government will not pursue an action against it because to do so would be fruitless.").

28 Cohen, Investment Advisers Act Release No. 3634, 2013 WL 3776681 (July 19, 2013), available at http://www.sec.gov/litigation/admin/2013/ia-3634.pdf.

z9 James Sterngold \& Jenny Strasburg, SAC: Cohen Didn't Read Key Email-While Poper for Employees by Hedge-Fund Firm's Lawyers Says Chief Executive Did Nothing Wrong, WALL ST. J., July 23, 2013, at C1 ("SAC Capital Advisors LP fired back at the U.S. government, telling employees Monday that the evidence shows Steven A. Cohen 'did not even read' the email at the heart of allegations he failed to take proper steps to prevent insider trading at his hedge-fund firm."). 
certification which is done knowingly but not willfully ${ }^{30}$ But like other types of offenses, the certification provision requires proof of at least knowledge, evidence that appears to have been in short supply in cases arising from the financial crisis. Moreover, the only conduct reached involves certification of financial statements and not broader activities that put a company at risk, which may be properly reported. ${ }^{31}$

\section{A. Responsible Corporate Officer Doctrine}

To get around the difficulties in proving a manager's knowledge or intent for the specific actions that violated the law, limited areas of federal law allow a conviction based largely on the person's official position and direct supervisory responsibility for the conduct, regardless of any actual involvement in the crime. Applying the "responsible corporate officer" doctrine extends the criminal law to those in a position of authority in an organization by requiring only proof of negligence or even imposing strict liability when there is a violation.

The responsible corporate officer doctrine is a way to hold managers liable for conduct by those under their direct supervision by eliminating the traditional requirement for criminal responsibility that depends on proving the defendant engaged in the prohibited conduct-or caused the particular harmwith the requisite intent. Instead, this approach imposes vicarious liability on an officer or director based on the person's supervisory position within the company and their negligent failure to prevent a violation. ${ }^{32}$ Under the doctrine, a senior corporate official can be punished for a lower-level employee's criminal activity, even

so 18 U.S.C. $\$ 1350$ (c) (2012). The penalty for a knowing violation is a maximum fine of $\$ 1$ million and up to 10 years in prison, while a knowing and willful violation can result in a $\$ 5$ million fine and up to 20 years in prison. $I d$.

31 Along the same lines, the SEC can seek to claw hack up to a year's worth of bonuses and other compensation awarded the chief executive officer and chief financial officer if the company issued a restatement of its financial statements. 15 U.S.C. $7243(a)$ (2012). Like $\$ 1350$, this provision is limited to restatements and only covers two senior executives and not others in management who may be responsible for misconduct by the organization.

32 "The accused, if he does not will the violation, usually is in a position to prevent it with no more care than society might reasonably expect and no more exertion than it might reasonably exact from one who assumed his responsibilities." Morissette $y$. United States, 342 U.S. 246, 256 (1952). 
though the officer did not participate in, and may have been unaware of, the actual conduct. ${ }^{33}$ Liability is based on the person's responsibility within the organization and authority to prevent or correct a violation, so that the crime occurs when the person's failure to act results in a violation taking place. The intent standard can be negligence, which requires proof that the corporate official did not act reasonably to prevent the violation, or in some instances strict liability, which requires proof of only a violation to hold corporate officers liable. ${ }^{34}$ This approach eliminates defenses typically seen in corporate crime cases, such as good faith or a lack of knowledge, so long as it can be shown that the official failed to prevent misconduct by others for whom the person is responsible. This is quite unlike the traditional approach to aiding and abetting a crime that depends on showing intent to commit the underlying offense. ${ }^{35}$ The responsible corporate officer doctrine substitutes supervisorial authority and the consequent failure to prevent a violation as sufficient to support a criminal conviction.

The doctrine has been upheld twice by the Supreme Court, in United States U. Dotterweich ${ }^{36}$ and United States v. Park. ${ }^{37}$ In Dotterweich, the Court affirmed the misdemeanor conviction of the president of a company for a misbranding offense under the Food, Drug, and Cosmetic Act, even though the government was not

3 See United States v. Ming Hong, 242 F.3d 528, 531 (4th Cir. 2001) ("The gravamen of liability as a responsible corporate officer is not one's corporate title or lack thereof; rather, the pertinent question is whether the defendant bore such a relationship to the corporation that it is appropriate to hold him criminally liable for failing to prevent the charged violations . . .").

34 See Todd S. Aagaard, A Fresh Look at the Responsible Relation Doctrine, $96 \mathrm{~J}$. Crim. L. \& CRIMINology 1245, 1265 (2006) ("[J]ust as negligent crimes impose a duty to take care that onc's actions do not unintentionally eause a violation of the law, where the responsible corporate officer doctrine applies, a negligent erime prosecuted under the responsible corporate officer doctrine recognizes a duty to take care that one's failure to act does not unintentionally cause a violation of the law.").

35 See United States v. Bancalari, 110 F.3d 1425, 1429 (9th Cir. 1997) ("To be convicted [as a principal] of aiding and abetting [the commission of a crime], the jury must find beyond a reasonable doubt that the defendant "knowingly and intentionally aided and abetted the principals in each essential element of the crime." ) (emphasis added) (citation omitted).

36 U.S. 277 (1943).

37 U21 U.S. $658(1975)$. 
required to prove his actual knowledge of the misconduct. ${ }^{38}$ The Court held that the statute "dispenses with the conventional requirement for criminal conduct-awareness of some wrongdoing." 39 Finding that Congress intended to impose strict liability for any violation, the Court concluded that it was permissible to hold a corporate executive liable for the violation because

[b]alancing relative hardships, Congress has preferred to place it upon those who have at least the opportunity of informing themselves of the existence of conditions imposed for the protection of consumers before sharing in illicit commerce, rather than to throw the hazard on the innocent public who are wholly helpless. ${ }^{40}$

The Court stated that in the interest of protecting the public from adulterated drugs, the statute "puts the burden of acting at hazard upon a person otherwise innocent but standing in responsible relation to a public danger." 41 This analysis eliminates a claim that the defendant did not personally cause the violation, or acted in an "otherwise innocent" way. Those might be worthy considerations at sentencing, but they do not affect the application of the criminal law to the conduct in Dotterweich.

In Park, the Court reversed the court of appeals and upheld the conviction of the president of a supermarket chain for the presence of unsanitary conditions at two of the company's storage warehouses in violation of the Food, Drug, and Cosmetic Act.42 The defendant challenged the trial court's jury instruction, which permitted conviction "even if [the defendant] did not consciously do wrong," provided he "had a position of authority and responsibility in the situation out of which [the] charges arose." 43 The Court held that the statute "imposes not only a positive duty to seek out and remedy violations when they occur but also, and

se Dotterweich, 320 U.S. at 284 ("Hardship there doubtless may he under a statute which thus penalizes the transaction though consciousness of wrongdoing be totally wanting.").

Id. at 281 .

40 $I d$. at 285 .

41 . at $280-81$ (emphasis added).

42 Park, 421 U.S. at 666-67.

s3 $I d$. at 665 n.9 (citation omitted). 
primarily, a duty to implement measures that will insure that violations will not occur." 44

The responsible corporate officer doctrine was used recently in a case involving misbranded drugs. Three senior executives at Purdue Frederick Co. pleaded guilty to misdemeanor violations for failing to prevent the company from marketing misbranded OxyContin, a powerful pain killing medication. ${ }^{45}$ The three executives admitted that they had "responsibility and authority either to prevent in the first instance or to promptly correct the misrepresentations ... Purdue employees made regarding [the addictive nature of prescription drugs]." 46 The charges were based solely on their positions in the corporation, and they were "not charged with personal knowledge of the misbranding or with any personal intent to defraud." 47 The district court noted that "[t]he government is also convinced that the nature of the convictions of the individual defendants-based on strict liability for misbranding-will send a strong deterrent message to the pharmaceutical industry." 48 Substantial fines were imposed,49 along with an effort by the Department of Health and Human Services to exclude them from future involvement in federal healthcare programs based on the guilty pleas. ${ }^{50}$ This remedy would effectively end their careers in the pharmaceutical industry. ${ }^{51}$ Thus, the responsible corporate officer doctrine can

44 Id. at 672 .

45 Friedman v. Sebelius, 686 F.3d 813, 816 (D.C. Cir. 2012), The executives were the former president and $\mathrm{CEO}$, the executive vice president and chief legal officer, and the former chief scientific officer. See United States v. Purdue Frederick Co., 495 F' Supp. 2d 569, 570 n.2 (W.D. Va. 2007). The company is now named Purdue Pharma L.P.

46 Friedman, 686 F.3d at 817 (internal quotation marks omitted).

47 Purdue Frederick Co, 495 F. Supp. 2d at 571 .

48 Id. at 576. The district judge noted that it was a close question whether to sentence the defendants to a term of incarceration, but stated, "I find that in the absence of government proof of knowledge by the individual defendants of the wrongdoing, prison sentences are not appropriate." Id.

49 The individuals "agreed to pay a total of $\$ 34.5$ million to the Virginia Medicaid Fraud Unit's Program Income Fund." Id. at 573

$s$ See Friedman, 686 F.3d at 816 ("Based upon their convictions, the Secretary of Health and Human Services later excluded the individuals from participation in Federal health care programs for 12 years, pursuant to 42 U.S.C. $\$ 1320 \mathrm{a}-7(\mathrm{~b}) . "$ ").

st $I d$. at $823-24,828$ (upholding authority of HHS to exclude the defendants from federal healthcare programs but reversing a twelve-year ban as unsupported by tho record). 
have a substantial impact on an executive, even if there is no prison term imposed, because of the potential collateral consequences of a conviction. ${ }^{52}$

Application of the responsible corporate officer doctrine has been extended to other public welfare provisions, such as those regulating meat branding and inspections. ${ }^{53}$ In United States $v$. Wise, ${ }^{54}$ an antitrust case, the Supreme Court rejected an executive's argument that the law only applied to corporations and not individuals, and relying on Dotterweich concluded that the Sherman Act should be read "to apply to all officers who have a responsible share in the proscribed transaction." ${ }^{55}$

Another area in which the doctrine is used with some regularity involves violations of the Clean Water Act and Clean Air Act, both of which specifically provide that the definition of a "person" includes "any responsible corporate officer."' In United States $v$. Iverson, ${ }^{57}$ the Ninth Circuit explained that an executive came within the Clean Water Act when "the person has authority to exercise control over the corporation's activity that is causing the discharges. There is no requirement that the officer in fact exercise such authority or that the corporation expressly vest a duty in the officer to oversee the activity." 58

In United States v. Hanousek, 59 the Ninth Circuit upheld the conviction of a railroad supervisor for a violation of the Clean Water Act as a "responsible corporate officer" in connection with a ruptured pipeline that caused thousands of gallons of oil to flow into a river. ${ }^{60}$ The circuit court stated, "We conclude from the plain language of 33 U.S.C. $\S 1319$ (c)(1)(A) that Congress intended

5* See Joshua D. Greenberg \& Ellen C. Brotman, Strict Vicarious Criminal Liability for Corporations and Corporate Exccutives: Strelching the Boundaries of Criminalization, 51 AM. CRIM. L. REV. 79, 92 (2014) ("For the three executives who pled guilty in the Furdue Frederick case, however, the penaltics were severe-seemingly career-ending-and caused great damage to their reputations.").

s3 See, e-g., United States v. Jorgensen, 144 F.3d 550, 560 (8th Cir. 1998); United States v. Cattle King Packing Co., 793 F.2d 232, 235 (10th Cir. 1986).

s 370 U.S. 405 (1962).

5. $I d$. at 409 .

56 33 U.S.C. $\S 1319(\mathrm{c})(6)(2012) ; 42$ U.S.C. $\$ 7413(\mathrm{c})(6)(2012)$.

57 162 F.3d 1015 (9th Cir. 1998).

58 Id. at 1025 .

59 176 F.3d 1116 (9th Cir. 1999).

on Id. at $1118-20$. 
that a person who acts with ordinary negligence in violating 33 U.S.C. $\$ 1321$ (b)(3) may be subject to criminal penalties."61 The Fourth Circuit looked beyond formal titles in upholding the conviction of an officer responsible for a company's finances who refused to authorize an upgrade to a wastewater treatment system that had been clogged. In United States v. Ming Hong, ${ }^{, 2}$ the circuit court stated, "The gravamen of liability as a responsible corporate officer is not one's corporate title or lack thereof; [but] rather, ... whether the defendant bore such a relationship to the corporation that it is appropriate to hold him criminally liable for failing to prevent the charged violations of the CWA." 63 The punishment imposed on the defendant included a three-year term of imprisonment, ${ }^{64}$ a substantial penalty for a violation grounded on the responsible corporate officer doctrine.

There are limits to the application of the responsible corporate officer doctrine, the most important being when a statute requires proof of intent for the offense to occur. Liability cannot be based simply on the defendant's position in the company, at least so long as the violation required proof of knowledge and not just negligence or that it was a strict liability offense. In United States v. MacDonald \& Watson Waste Oil Co. ${ }^{65}$ the First Circuit reversed the conviction of a company's president and owner for violating a provision of Resource Conservation and Recovery Act that required proof of knowledge. ${ }^{66}$ The district court had instructed the jury that the defendant's role as the

61 Id, at 1121 .

62242 F.3d 528 (4th Cir. 2001).

63 $I d$. at 531 . The Fourth Circuit described the following evidence as sufficient to establish the defendant acted as a responsible corporate officer at the company:

[A]lthough Hong went to great lengths to avoid being formally associated with Avion, in fact he substantially controlled corporate operations. Furthermore, Hong was involved in the purchase of the filtration system and was aware, in advance, that the filtration media would quickly be depleted if used as Hong intended. And, the evidence supported a finding that Hong was in control of Avion's finances and refused to authorize payment for additional filtration media. Finally, Hong was regularly present at the Avion site, and discharges occurred openly while Hong was present. Accordingly, we affirm Hong's convictions.

Id. at $\mathbf{5 3 2}$.

64 Id. at 532 .

65933 F.2d 35 (1st Cir. 1991).

$66 \mathrm{Id}$. at 51 . 
responsible corporate officer could be sufficient to establish his liability; the circuit found the instruction improper because "[i]n a crime having knowledge as an express element, a mere showing of official responsibility under Dotterweich and Park is not an adequate substitute for direct or circumstantial proof of knowledge." 67

The responsible corporate officer doctrine has not been confined to just criminal cases. In People v. Roscoe, ${ }^{68}$ the California Court of Appeal held that individual corporate officers could be jointly and severally liable for civil penalties imposed for violations of a state environmental statute because "the responsible corporate officer doctrine applies to ... the tank laws, and thus subjects to liability ... a corporate officer who has 'a responsible share in the furtherance of the transaction which the statute outlaws."69 Other states have similarly applied the doctrine under their environmental laws to hold corporate employees responsible for civil penalties and remedial orders for violations by the company. ${ }^{70}$

\section{B. Should Responsible Corporate Officer Liability Be Applied More Broadly?}

The rationale for applying the responsible corporate officer doctrine is to create a means to prevent companies from undertaking hazardous activities that can threaten public safety and welfare. In Park, the Supreme Court addressed the balance between imposing criminal liability on a corporate officer uninvolved in the actual violation and the need to protect the public:

The requirements of foresight and vigilance imposed on responsible corporate agents are beyond question demanding, and perhaps onerous, but they are no more stringent than the public has a right to expect of those who voluntarily assume

67 Id. at 55 .

169 Cal. App. 4th 829 (Cal. Ct. App. 2008).

69 Id. at 832 (quoting United States v. Dotterweich, 320 U.S. 277, 284 (1943)).

70 See, e.g., In re Dougherty, 482 N.W.2d 485, 488-91 (Minn. Ct. App. 1992); Ind. Dep't of Envtl. Mgmt. v. RLG, Inc., 755 N.E.2d 556, 558 (Ind. 2001); Wash. Dep't of Ecology v. Lundgren, 971 P.2d 948, 951-53 (Wash. Ct. App. 1999); State v. Rollfink, 475 N.W.2d 575, 576 (Wis. 1991)- 
positions of authority in business enterprises whose services and products affect the health and well-being of the public that supports them. ${ }^{71}$

Similarly, in Dotterweich, the Court made clear its view that Congress sought to protect interests of the public over the interests of executives because the executives are privy to information that the public lacks. ${ }^{72}$ Liability is premised on the authority of the official within the organization to prevent a violation, or to promptly remedy one if it occurs, so that the threat to the public from the company's activity is minimized. ${ }^{73}$

The responsible corporate officer doctrine operates in situations in which the potential impact of a violation by the company is clear and the threat to public health and safety is of such significance that requiring management to carefully monitor its activities-under the specter of individual criminal prosecutionis a necessary complement to the usual measures taken to ensure compliance with the law. Adulterated drugs, unsanitary food conditions, and improper discharge of hazardous materials present a potentially significant threat to the general public, and can be activities so fraught with danger that imposing an additional layer of liability for corporate officials is appropriate. Requiring proof of negligence, or even imposing strict liability, may be acceptable when the costs of a violation are significant, as illustrated by the Gulf of Mexico oil spill in 2011-although even in that type of case, imposing criminal liability may be little more than a nod to public outrage, rather than an effort to prevent future misconduct. ${ }^{74}$

Extending the doctrine to the type of conduct that led to the financial crisis is open to question, however. Unlike an oil spill or sale of misbranded addictive pain medication, some of the

71 United States v. Park, 421 U.S. 658, 672 (1975).

72 Dotterweich, 320 U.S. at 285.

73 See Park, 421 U.S. at $673-74$ ('[T] he Government establishes a prima facie case when it introduces evidence sufficient to warrant a finding by the trier of the facts that the defendant had, by reason of his position in the corporation, responsibility and authority either to prevent in the first instance, or promptly to correct, the violation complained of, and that he failed to do so.").

${ }_{74}$ But see Greenberg \& Brotman, supra note 52, at 94 ("For nine reasons, many of which mirror the reasons why strict vicarious criminal liability for corporations should be rejected, the Park doctrine is unfair, is bad policy, and should be abolished."). 
"products" that were identified as contributors to the financial crisis, like credit default swaps and mortgage-backed securities, are part of a wide range of legitimate and commonplace corporate transactions. The problems occurred, at least in part, because of excessive risks taken by banks, insurance companies, and brokerages when creating and trading more exotic types of securities that transformed the housing market collapse into a global economic crisis. But that was not the only cause of the economic problems that afflicted banks: the Financial Crisis Inquiry Commission (FCIC) noted that there were "widespread failures in financial regulation"; "dramatic breakdowns of corporate governance"; "excessive borrowing" and risk-taking by households and Wall Street; policy makers who were "ill prepared for the crisis"; and systemic breaches in "accountability and ethics" at all levels. ${ }^{75}$

There is no doubt that the financial crisis caused significant harm to the stability of the global banking system in myriad ways, but it was not traceable to any single event or investment vehicle. As pointed out by a dissenting report from the FCIC, "[n]ot everything that went wrong during the financial crisis caused the crisis, and while some causes were essential, others had only a minor impact."76 Although one could analogize certain particularly risky derivatives to hazardous waste-described by Warren Buffett as "financial weapons of mass destruction" five years before the financial crisis, ${ }^{77}$-there is not a very good correlation between the types of violations seen in responsible corporate officer cases and the countless problems that lead up to the financial crisis, none of which can be easily identified as a direct cause or even a predominant contributor.

Constitutional issues regarding vagueness may also arise if certain types of corporate conduct were subject to prosecution under the responsible corporate officer doctrine. The void.for-

is Fin. Crists Tnquiry Comm'n, The FInANCLL ChISIS Inquiry RePort xviii, xxvii, xix, xxi, xxii (2011), available at http:/www.gpo.gov/fdsys/pkg/GPO-FCIC/pdf/GPOFCIC.pdf.

76 Id. at 414 (Dissenting Statement of Keith Hennessey, Douglas Holtz-Eakin, and Bill Thomas).

77 Letter from Warren E. Buffett, Chairman of the Bd., Berkshire Hathaway Inc., to Shareholders 15 (Feb. 21, 2003), auailable at http//www herkshirehathaway .com/letters/2002pdf.pdf. 
vagueness analysis looks to whether a statute provides fair notice about what conduct constitutes a crime and whether the prohibition is so broad that it would permit the government to pursue arbitrary and discriminatory prosecutions. ${ }^{78}$ The Supreme Court has been particularly concerned that a broadly defined offense that relies on standards like fiduciary duty might result in prosecutions based more on the personal predilections of individual prosecutors than an application of fair standards. ${ }^{79}$ In Skilling, the Court warned against adopting a statute reaching undisclosed conflicts of interest "while purporting to act in the interests of those to whom he owes a fiduciary duty," because "[t]hat formulation . . leaves many questions unanswered. How direct or significant does the conflicting financial interest have to be? To what extent does the official action have to further that interest in order to amount to fraud? To whom should the disclosure be made, and what information should it convey?"80 If a corporate official could be punished based only on what a subordinate did, then similar questions about culpability could be raised, especially for offenses like mail and wire fraud that carry potential sentences of thirty years imprisonment for each violation. ${ }^{81}$

If corporate officers could be charged with crimes based on their negligent failure to prevent widespread financial harm, or even be held strictly liable, the question would then become: how do we define the types of decisions that would be subject to the criminal prohibition?s2 Buying and selling securities tied to

78 See Kolender v. Lawson, 461 U.S. 352,357 (1983) ("As generally stated, the voidfor-vagueness doctrine requires that a penal statute define the criminal offensc with sufficient definiteness that ordinary people can understand what conduct is prohibited and in a manner that does not encourage arbitrary and discriminatory enforcement.").

79 $I d$. at 358 ("Where the legislature fails to provide such mimimal guidelines, a criminal statute may permit 'a standardless sweep [that] allows policemen, prosecutors, and juries to pursue their personal predilections."”) (quoting Smith v. Goguen, 415 U.S. 566, 575 (1974)).

so Skilling v. United States, 561 U.S. 358, 411 n.44 (2010).

s1 18 U.S.C. §与 1341, 1343 (2012).

g2 For example, the controversy over the failure by General Motors to timely recall vehicles with a defective ignition switch that caused at least thirteen deaths was blamed largely on negligence by lower level employees with senior management kept in the dark about the problem, at least according to a report of the company's internal investigation. See Bill Vlasic, G.M. Inquiry Ciles Years of Neglect Over Folal Defect, N.Y. TIMES, June 5, 2014, http:/www.nytimes.com/2014/06/06/business/gm-ignition- 
subprime loans or offering mortgages to those with questionable financial means-the so-called liars' loans ${ }^{83}$-is legal, even if a questionable business decision. At what point do those activities become such a threat that a responsible corporate officer should have taken steps to prevent the likely harm, assuming such an ex ante assessment could be made? Unlike a manager aware of a rat infestation at a food storage facility or a supervisor learning of problems with waste disposal who does nothing to thwart the expected violation, the financial impact from otherwise legal transactions may not be known for months or even years, if ever.

If the responsible corporate officer doctrine was used in conjunction with a negligence standard for corporate decisions that turn out to cause significant financial harm to investors and the economy, then management can be expected to avoid policies and investments that involve any appreciable threat of triggering significant losses. But such loss avoidance runs counter to the usual approach to corporate decision-making; a certain measure of risk must be undertaken to develop a business and generate reasonable returns. The only approach virtually guaranteed to involve no appreciable risk of loss is doing nothing, but that also means there will be little if any return on investment.

Extending criminal liability to officials in financial industries, as well as other lines of business that can have a broad economic impact based on the responsible corporate officer doctrine, could have the effect of deterring investments that create jobs and grow the economy. There is risk in any transaction, and while it is easy to say that "excessive" risk-taking should be deterred, defining what is outside acceptable bounds is not easy to do. Using the responsible corporate officer doctrine to impose liability on corporate executives in a manner similar to drug

switch-internal-recall-investigation-reporthtml. If executives were unaware of the problem, then it would be difficult to pursue a prosecution against thom even under the more forgiving "responsible corporate officer" doctrine.

s See Charles W. Murdock, The Dodd-Frank Wall Street Reform and Consumer Protection Act: What Caused the Financial Crisis and Will Dodd-Franh Prevent Future Crises?, 64 SMU L. REV. 1243, 1257 (2011) ("As the subprime market developed in the mid-2000s, prospective borrowers were encouraged to be unscrupulous by the explosion of the so-called 'liars' loans.' These loans evolved from stated income loans, in which the borrower did not need to document income and that made some sense for a selfemployed person, into 'stated asset' loans, in which the borrower need document neither income nor assets."). 
safety and environmental cases might end up causing much more economic harm than good, even if it would make it easier to prosecute corporate officials for decisions that turn out badly.

\section{GERmany's ABuse of TRUST Sta'tute}

Unlike the United States, Germany does not permit a corporation (Aktiengesellschaft) to be prosecuted for a violation of the criminal law. ${ }^{84}$ There are, however, quasi-criminal sanctions that can be imposed on a company by means of the German Administrative Offenses Act (Ordnungswidrigkeitengesetz) (OWiG), such as forfeiture and fines. ${ }^{85}$

Among the tools available to German prosecutors is Section 266 of the German criminal code (Strafgesetzbuch), the crime of breach of trust (Untreue) by a corporate officer:

Any person who by law, administrative delegation or contract has dispositional power over the assets of others or power to commit these assets to a third party, abuses and breaches the duty laid on him by law, administrative delegation or trust relationship to protect the property interests of another, and in this way causes damage to the property interests that he

*4 See Martin Böse, Corporale Criminal Liability in Germany, in CORPORATE CRIMINAL LIABILITY: EMERGENCE, CONVERGENCE, AND RISK 227, 228 (Mark Pieth \& Radha Ivory eds., 2011) ("'T]he Gcrman Penal Code does not provide for the imposition of criminal sanctions on corporations. In drafting the code in 1870 , the German legislator adhered to a notion of personal guilt that could not be applied to corporations; following the ancient rule, societas delinquere non potest, it limited criminal liability to natural persons.").

ss Ordnungswidrigkeitengesetz [OWiG] [Code of Administrative Offenses], May 24, 1968, BuNDESGESETZBLATT [BGBL.] I at 481, repromulgated Feb. 19, 1987, BGBL. I at 602, last amended Oct. 10, 2013, BGBL. I at 3796, $\$ 30$ (Ger.). See Roland Hefendehl, Corporate Criminal Liability: Model Penal Cade Section 2.07 and the Development in Westem Legal Systems, 4 BUFF. CrIM. L. REv. 283, 286 (2000) ("In Germany, liability is imposed on corporations by state authorities only for administrative offenses. There is much debate about whether such penalties should be considered criminal sanctions or morally neutral administrative penalties. The German law of Ordnungswidrigheiten (administrative penalties) empowers administrative authorities as well as criminal courts to impose administrative fines (Geldbujen) on both natural persons and companies."). 
should protect, shall be punished with arrest of up to five years or with a monetary fine. ${ }^{86}$

The statute requires proof of an abuse or breach of duty that "causes damage to the property interests that he should protect."87 The source of that duty in the corporate context is Section 93 of the German Stock Corporation Act (Aktiengesetz), which imposes an obligation on both the management board and the supervisory board to "employ the care of a diligent and conscientious manager."88 For a company organized under foreign law but operating in Germany, the foreign jurisdiction's requirements for corporate directors and officers will determine whether there is a breach of duty for a violation. ${ }^{89}$ German corporate law provides that there is no violation of duty "if, at the time of taking the

36 Strafgosetzbuch [StGB] [Penal Code], Nov. 13, 1998, BGBL. I at 3322, last amended Apr. 23, 2014, BGBL. I at 410, $\$ 266$ (Ger.), translated in Franklin A. Gevurtz, Disney in a Comparalive Light, 55 AM. J. CoMP. L. 453, 461 (2007).

87 Id.

sa Aktiengesetz [AktG] [Stock Corporation Act], Sept. 6, 1965, BGBi. I at 1089, last amended July 23, 2013, BGBL. I at 2706, § 93(1) (Ger.), translated in Thomas J. André, Jr., Some Reflections on German Corporate Governance: A Glimpse at German Supervisory Boards, 70 TUL, L. REv, 1819, 1824 (1996). German corporations have two separate hoards: the supervisory hoard (Aufsichtsrat) and the management board (Vorstand). André, supra, at 1823 . The supervisory board appoints the members of the management board, which is responsible for the day-to-day operation of the company. Id. The supervisory board is charged with supervision of the management board, much like the firectors of an American corporation are responsible for monitoring management but do not get involved in the daily decisions of running a business. Id. at $1823+24$. But the supervisory board has a broader mandate, so that "the supervisory board concept originated as a kind of substitute for regulation that had previously been undertaken by the state, and indeed, the Aktiengeset $z$ [German corporate code] itself clearly envisions a much stricter separation of board functions than exists on a unitary board," Id. at 1824. Today, "the supervisory board is now significantly involved in the decision-making process on a company's overall strategic concept and on management decisions of fundamental importanee." Jan Lieder, The German Supervisory Board on. Its Way to Professionalism, 11 GERMnN L.J. 115, 117 (2010). Unlike the board of directors of a United States corporation, however, supervisory boards of large German corporations "must have twenty seats (twenty-one seats in the coal and steel sector), half of which must be filled by labor." Klaus J. Hopt, Comparative Corporate Governance: The State of the Art and International Regulation, 59 AM. J. CoMP. L. 1, 24 (2011).

*9 See Manuel Ladiges, Criminal Liability of Directors of a Private Limited Company Seated in Germany, 24 CRIM. L.F. 87, 103 (2013) ("Since the company law of the incorporation state is authoritative for the defendant's duties as a director, the Federal Supreme Court hold, that German courts must interpret $\$ 266(1)$ StGB in the light of the relevant foreign company law."). 
entrepreneurial decision, they had good reason to assume that they were acting on the basis of adequate information for the benefit of the company." This is similar to the Business Judgment Rule employed in the United States to evaluate the decisions of corporate officers and directors. Under Delaware law, the predominant jurisdiction for articulating American corporate law, there "is a presumption that "in making a business decision the directors of a corporation acted on an informed basis, in good faith and in the honest belief that the action taken was in the best interests of the company [and its shareholders]."'91

An important distinction from the obligations of directors in the United States is that the German supervisory board members must act only for the benefit of the organization (Unternehmensinteresse) distinct from its owners, including stakeholders. ${ }^{92}$ They must safeguard the company's property so that it is used only for the benefit of the business as a continuing entity. The supervisory board, which includes union representation, does not owe duties directly to the shareholders and must protect the interests of employees. ${ }^{93}$ Supervisory board members do not participate in the day-to-day decisions regarding

9n Aktiengesetz [AktG] [Stock Corporation Act], Sept. 6, 1965, BGBL. 1 at 1089, last amended July 23, 2013, BGBL. I at 2706, \$ 93(1) (Ger.), translated in NoRTON ROSE LLP, STOCK CORPOLATION ACT 48 (2011), available at http:/www.nortonroseful bright.com/files/german-stock-corporation-act-2010-english-translation-pdf-59656.pdf.

9t See Emerald Partners v. Berlin, 787 A.2d 85, 90 (Del. 2001) (quoting Aronson v. Lewis, 473 A.2d 805, 812 (Del. 1984)).

92 See Theodor Baums \& Kenneth E. Scott, Taking Shareholder Protection Seriously? Corporate Governance in the United States and Germany, 53 AM. J. CoMP. L. $31,54-55$ (2005) ("The duties provided for by law flow from the duty of loyalty that each supervisory board member owes to the corporation. The purpose of these duties, however, is by no means exclusively to protect the interests of the shareholders. The majority position is that the supervisory board must primarily protect the interests of the firm (Unternehmensinteresse)."); Florian Stamm, A Comparative Study of Monitoring of Management in German and U.S. Corporations After Sarbanes-Oxley; Where Are the German Enrons, WorldComs, and Tycos?, 32 GA. J. INT'L \& COMP. L. 813, 826 (2004) ("Beyond the general standard of care, there is a duty to act affirmatively on behalf of the corporation.").

93 See Martin Gelter, Taming or Prolecting the Modern Corporation? ShareholderStakeholder Debates in a Comparative Light, 7 N.Y.U. J.L. \& Bus, 641, 678 (2011) ("The German corporate governance system is notorious for its focus on stakeholder interests. The main reason is codeternination on German supervisory boards, which creates a limited, but significant influence of employees on corporate decision-making by granting them a number of mandatory seats."). 
the company's operations, and the direct obligation to protect the company's assets falls to the managerial board members. ${ }^{94}$ As such, the supervisory board's obligation is to oversee the managerial board, ${ }^{95}$ so Section 266 is one means to enforce the obligation of corporate officials to put the company's best interests first if decisions result in significant damage to the enterprise.

Section 266 has been used in two high profile prosecutions of corporate officials in Germany: the Mannesmann AG award of additional compensation to its former chief executive by members of the supervisory board, ${ }^{96}$ and the payment of overseas bribes by employees of Siemens AG.97 These cases illustrate the potential breadth of pursuing corporate executives for an abuse of trust based on damage to the company from their decisions.

The Mannesmann case arose from the first successful hostile takeover of a German corporation when Vodafone PLC acquired the company in 2000.98 Klaus Esser became Mannesmann's CEO in 1999 after serving as its chief financial officer. ${ }^{99}$ In 2000, after protracted negotiations, he helped secure a significant increase in the offer price from Vodafone, generating approximately $€ 63$ billion in increased value for the shareholders. ${ }^{100}$ Members of a "non-executive compensation committee" of Mannesmann's supervisory board were responsible for determining the compensation of its executives, and awarded Esser a $€ 15$ million payment on the day the transaction closed: a reward for his work in negotiating a higher bid.101 Other corporate officers also received bonuses, totaling $€ 60$ million, and the disclosure of the awards caused an immediate outcry in Germany. ${ }^{102}$ The initial

94 See Stamm, supra note 92 , at 827 .

95. Id.

* See generally Peter Kolla, The Mannesmann Trial and the Role of the Courts, 5 GERMAN L.J. 829 (2004).

n See generally Markus Adick, Risks for Firms and Their Executives in Cases of Corruption-An Overview with Parlicular Regard to the Siemens Case, NEw J. EUR. Crim. L. (SPECLAL EdJTION) 25 (2009).

92 See Kolla, supra note 96 , at 829 .

sg See Gevurtz, supra note 86 , at 460 .

$100 \mathrm{Id}$.

101 See Kolla, supra note 96 , at 832 .

to2 Id. 
claim was that these were bribes paid to management to persuade them to go along with the Vodafone offer. ${ }^{103}$

Esser and other members of the supervisory board, including former Deutsche Bank CEO Dr. Josef Ackermann, were charged with violating Section 266 by a local prosecutor in Düsseldorf. 104 The highly anticipated proceeding-described as "the first criminal trial in Germany against leading persons of a stock corporation"ended with the trial court acquitting the defendants. ${ }^{105}$ Although the judge found that they had breached a fiduciary duty to the company, they did not violate the criminal provision because Section 266 was limited to only an "aggravated" breach of duty, ${ }^{106}$ This did not occur because the company's profits were never threatened and the supervisory board members "did not have an unlawful purpose."107 As one commentator noted, "the judge pointed out that it was the court's obligation to decide whether the defendants' behaviour was relevant for criminal law, not to estimate corporate culture by making moral or value judgments."108

The prosecutor appealed to the German Federal Court of Justice (Bundesgerichtshof) (BGH), which reversed the acquittal and returned the case to the lower court. ${ }^{109}$ The $\mathrm{BGH}$ rejected the

103 Id. at 832-33. ("Allegations of bribery initially surrounded Esser's appreciation award. Esser had spent over $€ 200$ million resisting Vodafone's hostile takeover bid, and questions arose as to whether the award had improperly bought Esser's support for the takeover.").

104 See Gevurtz, supra note 86 , at 460.62.

tos Max Philipp Rolshoven, The Last Word?-The Iuly 22, 2004 Acquitials in the Mannesmann Trial, 5 GERMAN L.J. 935, 936 (2004).

10 See Gevurtz, supra note 86 , at 462 .

107 Id. ("The trial court concluded that, while the directors had breached their duty in awarding the bonus, they were not criminally liable. This was because, according to the trial court, there must be an 'aggravated' breach of duty in order for a business judgment to violate Section 266 of the Penal Code. In this case, the trial court found the breach was not aggravated, because the company's profits were high and the continuity and the profitability of the company werc never threatened, the decision was made diligently and in a transparent manner in accordance with the allocation of responsibility within the company, and the members of the Supervisory Broard did not have an unlawful purpose.").

I0s Rolshoven, supra note 105 , at 940 .

1 Se Sevurtz, siupra note 86 , at 462 . Under the Double Jeopardy Clause in the United States, a judicial acquittal based on insufficient evidence could not be appealed to a higher court. See, e.g., Fong Foo v. United States, 369 U.S. 141, 143 (1962) (holding that acquittal by directed verdict cannot be appealed by the prosecution); United States 
argument that Section 266 was too indefinite-"vague" in the parlance of United States law-to be enforced, finding that it met the requirements of Article 103(2) of the Basic Law for the Federal Republic of Germany (Grundgesetz).110 That provision states, "An act may be punished only if it was defined by a law as a criminal offense before the act was committed."11 The BGH further found that a violation of Section 266 did not require a "serious" breach of the supervisory board's duty to the company. ${ }^{12}$ The case was sent back to the lower court for consideration of whether the defendants could offer an "ignorance of the law" defense113 under Section 17 of the Criminal Code, which provides, "If at the time of the commission of the offence the offender lacks the awareness that he is acting unlawfully, he shall be deemed to have acted without guilt if the mistake was unavoidable." 114 The defendants subsequently agreed to pay $€ 5.8$ million before a second trial, and the prosecutor dropped the charges. 115

In the second high profile case, a former manager at Siemens $\mathrm{AG}$ and an outside consultant were convicted of violating Section 266 for creating a "slush fund" with corporate assets used to pay bribes to foreign government officials to win contracts for the company. ${ }^{116}$ Under United States law, this would be a violation of the Foreign Corrupt Practices Act, which prohibits giving anything of value to any person affiliated with another government to "obtain[] or retain] business" in that country. ${ }^{117}$ While Germany has also made such conduct a crime, that offense did not become punishable until 2002, and at least some of the

\footnotetext{
v. Scott, 437 U.S. 82, 91 (1978) (holding that "acquittal, whether based on a jury verdict of not guilty or on a ruling by the court that the evidence is insufficient to convict, may not be appealed").

110 Stefan Maier, A Close Look at the Mannesmann Trial, 7 German L.J. 603, 60607 (2006).

111 Id. at $606 \mathrm{n} .21$.

112 Id. at 608 .

113 See Gevurtz, supra note 86, at 462 .

114 Straftesetzbuch [StGB] [Penal Code], Nov. 13, 1998, BGBL. I at 3322, last amended Apr. 23, 2014, BGBL. I at 410, § 17 (Ger), translation aualable at http:/www.gesetze-im-internetde/englisch_stgb/englisch_stgb.html ("If the mistake was avoidable, the sentence may be mitigated pursuant to section $49(1) . ")$.

115 See Gevurt2, supra note 86, at 462

116 See Adick, supra note 97, at 25.

11715 U.S.C. $\$ 78 \mathrm{dd}-1$ (2012).
} 
payments at issue occurred before that date. ${ }^{118}$ The abuse of trust statute permitted prosecutors to pursue the case because the corporate officer's misuse of funds breached his fiduciary duty to the company and exposed it to potential harm, even though the goal of the illicit payments was to assist Siemens to acquire additional business. 119 The company itself paid a total of $\$ 1.6$ billion in fines, penalties and disgorgement, including $\$ 800$ million to the Department of Justice and the SEC, to settle criminal and civil cases in the United States and Germany for the bribes. 120

The conviction was appealed to the Federal Constitutional Court (Bundesverfassungsgericht) (BVerfG), which reviewed it along with two other cases involving violations of Section 266.121 In one prosecution, the chairman of a health insurance company funneled premiums to employees in excess of their salary and other compensation beyond what he was authorized to provide.122 In the other, members of the board of Berlin-Hannoversche Hypothekenbank authorized a real estate loan without the proper information and investigation which would have shown it was not adequately secured. ${ }^{123}$ The $B V$ erfG rejected the argument that the statute was unconstitutional, finding that it met the requirements of Article 103(2) because the courts had interpreted the provision with enough precision so that there were appreciable boundaries to the law. ${ }^{124}$ The court rejected the conviction of the bank board members, however, because it found there was no crime of attempted abuse of trust. ${ }^{125}$ The corporate decision that is alleged to constitute a violation of Section 266 must result in harm at the

\footnotetext{
(15 See Adick, supra note 97 , at 27.

119 Strafgesetzbuch [StGB] [Penal Code], Nov. 13, 1998, BGBL. I at 3322, last amended Apr. 23, 2014, BGBL. I at 410, $\$ 266$ (Ger.).

120 See Press Release, U.S. Dep't of Justice, Siemens AG and Three Subsidiaries Plead Guilty to Foreign Corrupt Practices Act Violations and Agree to Pay \$450 Million in Combined Criminal Fines (Dec. 15, 2008), auailable at http://www.justice.gov/opa/pr/2008/December/08-crm-1105.html.

181 See Press Release, Fed. Constitutional Court of Ger. Press Office, Constitutional Complaints Against Convictions for Abuse of Trust Partially Successful (Aug. 11, 2010), available at http://www.bverfg.de/en/press/bvg10-060en.html.

LI2 Id.

123 Id.

1*A Id.

Los Id.
} 
time it was made, not just that there be "harm by endangerment" depending on how the transaction develops. ${ }^{226}$

The issue of excessive executive compensation in the Mannesmann case is usually addressed in the United States through a shareholder derivative suit, although such challenges generally fail. For example, questions about the $\$ 140$ million paid by Disney to a former CEO whose short tenure was fraught with difficulties resulted in a finding that the board of directors did not breach its fiduciary duty in approving the pay package. ${ }^{127}$ The standard the Delaware court applied was whether the payment constituted corporate waste, which requires a showing of bad faith. ${ }^{128}$ Although the BGH did not explain what level of intent was required to violate Section 266 in the Mannesmann case, the availability of the defense provided in Section 17 for a mistake indicates that there must be some measure of intentionality because a lack of awareness that conduct is unlawful can prevent a conviction. In the Siemens case, the question of intent was not considered because the corporate official knew that the funds were to be used for an improper purpose, even if there was no intent to cause harm to the enterprise.

The contours of Section 266 can be discerned from these cases. The statute is quite broad in its application, available for any corporate misconduct that results in a loss to the entity. ${ }^{129}$ The key to proving a violation is the harm to the organization, not that the defendant realized any personal gain from the misconduct. While the normal measure of harm in the corporate context would be in monetary terms, such as in a fraud case, there is no balancing of interests like an assessment of whether the impact was substantial or that shareholders realized a greater benefit even if the entity suffered a comparatively small loss. The mistake of law defense available to a defendant accused of a Section 266 violation shows the conduct must at least be reckless by triggering a direct risk of loss, not merely negligent. A manager

\footnotetext{
126 Id.; see Strafgesetzbuch [StGB] [Pena] Code], Nov. 13, 1998, BGBL. I at 3322, last amended Apr. 23, 2014, BGBL. I at 410, 266 (Ger.).

127 Brehm v. Eisner, 746 A.2d 244, 260-62 (Del. 2000).

128 Id. at 263.

129 Strafgesctzbuch [StGB] [Penal Code], Nov. 13, 1998, BGBt. I at 3322, last amended Apr. 23, 2014, BGBL, I at 410, $\$ 266$ (Ger.).
} 
pursuing an informed decision, particularly one based on legal advice from competent attorneys, will be able to avoid liability. In addition, the decision that causes harm to the enterprise must have an immediate effect, even if it does not come to light until years later, like the overseas bribery at Siemens. It is not a violation when the harm is only traceable to a risky-but defensible-business decision that turned out to cause a loss, like the bank loan at Berlin-Hannoversche Hypothekenbank.

Section 266 resembles the "right of honest services" theory of mail and wire fraud in the United States, which was available for prosecutions before 2010, when the Supreme Court restricted its scope in Skilling v. United States. ${ }^{130}$ The federal statute, 18 U.S.C. $\$ 1346$, provides that a deprivation of the intangible right of honest services is treated like a fraud involving money or property. Along the same lines as the breach of trust that causes harm to an organization punishable under Section 266, the right of honest services was applied in cases in which corporate officials breached their fiduciary duty to the company in the hope of realizing some benefit; the theory was applicable as long as the company suffered some detriment to its interests, even if the company did not have any monetary harm or was not even the source of the benefit. 131 Thus, a conflict of interest or self-dealing could be the basis for a mail or wire fraud conviction even if the party to whom the honest services were owed did not lose anything directly. ${ }^{132}$

130561 U.S. 358,368 (2010).

131 The Second Circuit explained the theory of honest scrvices fraud this way:

[A] scheme or artifice to use the mails or wires to enable an officer or employee of a private entity (or a person in a relationship that gives rise to a duty of loyalty comparable to that owed by employees to employers) purporting to act for and in the interests of his or her employer (or of the other person to whom the duty of loyalty is owed) secretly to act in his or her or the defendant's own interests instead, accompanied by a material misrepresentation made or omission of information disclosed to the employer or other person.

United States v. Rybicki, 354 F.3d 124, 141-42 (2d Cir. 2003).

132 Perhaps the broadest statement of the honest services doctrine came in United Slates v. Bronston, 658 F.2d 920 (2d Cir. 1981), in which a law firm partner (and state senator) was convicted for not disclosing to a client that he was representing the interests of a competitor seeking a government contract. According to the Second Circuit, "[a]lthough a mere brcach of fiduciary duty, standing alone, may not necessarily constitute a mail fraud, the concealment by a fiduciary of material 
For example, in United States v. Black, ${ }^{193}$ a former CEO, Conrad Black, and other executives at a publicly traded media company were convicted of mail and wire fraud for their conduct. in negotiating agreements to sell chains of small newspapers and then diverting a portion of the funds under the guise of noncompetition agreements and management fees. ${ }^{134}$ Prosecutors accused Black of committing fraud under two theories: as an ordinary fraud, in which the company lost the funds by embezzlement or theft; and for depriving the intangible right of honest services by putting his own interests ahead of the organization. ${ }^{135}$ On the honest services theory, the jury was instructed that "all it had to find was that in failing to disclose the recharacterization of the management fees to the audit committee and the board, they had failed to render honest services to Hollinger and had done so in an effort to obtain a private gain." 136

In Skilling, the Supreme Court narrowed the right of honest services theory of fraud to "only the bribe-and-kickback core" that had been prosecuted before the enactment of $\S 1346$ in 1988.137

information which he is under a duty to disclose to another under circumstances where the non-disclosure could or does result in harm to the other is a violation of the statute." Id. at 926 (citations omitted).

1.33 625 F.3d 386 (7th Cir. 2010).

134 The Seventh Circuit described one of the transactions in this way:

The first of these counts concerns a subsidiary of Hollinger called $\mathrm{AP}^{\mathrm{P}} \mathrm{C}$, which owned a number of small community newspapers that it was in the process of selling. When it had only one left-a weekly community newspaper serving Mammoth Lake, California (population 7,098 in 2000, the year before the fraud) defendant Kipnis, Hollinger's general counsel, prepared and signed on behalf of APC an agreement to pay the other defendants, plus another Hollinger executive, a total of $\$ 5.5$ million in exchange for their promising not to compete with APC for three years after they stopped working for Hollinger. The money was paid. Neither Hollinger's audit committec, which was required to approve transactions between Hollinger's executives and the company or its subsidiaries (such as APC) because of the conflict of interest, nor Hollinger's board of directors, was informed of this transaction. That Black and the others might start a paper in Mammoth Lake to compete with $A P^{\prime}$ 's tiny newspaper there was a ridiculous idea; no one would pay them to promise not to do something they obviously would never want to do.

Id. at 391 .

$135 \mathrm{Id}$.

$136 \mathrm{Id}$.

137 Skilling v. United States, 561 U.S. 358 , 409 (2010). Congress adopted the statute in response to the Supreme Court's decision in McNally v. United States, 483 U.S. 350 (1987), which held that the mail and wire fraud statutes did not reach schemes to 
The Court rejected the government's argument that the statute also applied to self-dealing and non-disclosure cases in which there was an element of deception that constituted a scheme to defraud the right of honest services, finding that "[i]n light of the relative infrequency of conflict-of-interest prosecutions in comparison to bribery and kickback charges, and the intercircuit inconsistencies they produced, we conclude that a reasonable limiting construction of $\S 1346$ must exclude this amorphous category of cases," 138 By limiting the statute to only bribery and kickback cases, the Court found the provision was sufficiently clear and that it was not unconstitutionally vague. ${ }^{139}$ Skilling did not explain exactly what constitutes a kickback, a much more amorphous term than bribery, but both terms connote the defendant receiving something the person was not entitled to, which is provided by someone with an interest in the underlying transaction. 140

Unlike Section 266, which focuses on the harm to the entity owed the fiduciary duty, Skilling made the key to proving a right of honest services fraud case an improper gain realized by the defendant, without regard to any harm suffered by the company. That distinction makes this theory much less useful in prosecuting instances of corporate mismanagement resulting in substantial harm to the enterprise and even the wider public. In Skilling, the Court noted that the government's honest services theory at trial rested on the chief executive's misstatements about the company resulting in his receiving salary and bonuses, along with selling shares at an inflated value, thus showing the benefits he received from his dishonesty.141 That was insufficient, however, because there was no allegation that the defendant "solicited or accepted

\footnotetext{
defraud the citizens of the intangible right of honest services, but only money or property. The Court stated, "Rather than construe the statute in a manner that leaves its outer boundaries ambiguous and involves the Federal Government in setting standards of disclosure and good government for local and state officials, we read $§$ 1341 as limited in scope to the protection of property rights." Id. at 360.

138 Skilling, 561 U.S. at 410 .

159 Id. at 412 ("Interpreted to encompass only bribery and kickback schemes, $\$ 1346$ is not unconstitutionally vague.").

140 Like the Supreme Court did in Skilling, the Seventh Circuit reversed Black's honest services conviction and remanded the case for further review by the lower courts. See Black, 625 F.3d at 393-94.

141 Skilling, 561 U.S. at 413.
} 
side payments from a third party in exchange for making these misrepresentations." 142 'Thus, unless it can be shown that an executive manipulated the company to increase the compensation that would be paid, or triggered bonuses or other forms of remuneration the person was not otherwise entitled to, it will be impossible to bring a fraud prosecution based on risky decisions that might have caused only substantial and unjustifiable harm to the company. If the manager stays within the terms of the employment contract, then a breach of a fiduciary duty, even one accompanied by deception, will fall outside the scope of the mail and wire fraud statutes and not be subject to prosecution as an honest services violation.

At one time, there was an apparent overlap between Section 266 of the German criminal code for an abuse of trust and § 1346's definition of fraud based on a deprivation of the right of honest services, in that both focused on a violation of a corporate official's obligations to the organization as the basis for imposing criminal liability. Now, Skilling has made the United States fraud law much less effective in policing corporate decision-making that inflicts substantial damage on the company and the wider economy. The Mannesmann prosecution began with the view that the company's CEO was bribed to permit the merger, but prosecutors dropped that theory because the extra compensation appeared to be only a reward, which does not constitute a bribe because there is no quid pro quo arrangement. ${ }^{143}$. While the purported harm to the company was sufficient to bring the case within Section 266, it could not be charged as a violation of the right of honest services statute after Skilling without relying on the bribery theory rejected by the German prosecutors. ${ }^{144}$

$142 I d$.

143 See, e.g., United States v. Bruno, 661 F.3d 733, 743 (2d Cir. 2011) ("Bruno argues that the government failed to provide sufficient proof of a quid pro quo, an essential element of a bribery theory of honest services fraud. We disagree. A quid pro quo is a government official's receipt of a benefit in exchange for an act he has performed, or promised to perform, in the course of the exercise of his official authority.") (citation amitted).

144 Germany adopted a much narrower provision targeting senior executives of banks and insurance companies who fail to comply with risk management procedures in violation of an administrative directive. Kreditwesengesetz [KWG] [Banking Act], Sept. 9, 1998, BGBL. I at 2776, last amended July 15, 2014, BGBL. I at 934, $54 a$ (Ger). The new portion of the Act, which went into effect on January 1, 2014, makes it 


\section{BRITAIN'S RECKLESS BANKER LAW}

The financial crisis hit the British banking sector as hard as any country's in the world, with government bail-outs of banks like Royal Bank of Scotland, Northern Rock, and HBOS requiring the government to provide over $\mathfrak{\&} 1$ trillion in support. ${ }^{145}$ The Parliamentary Commission on Banking Standards (Commission) issued a report on the demise of $\mathrm{HBOS}$, once the leading mortgage and savings institution in the country, with the title "An accident waiting to happen." 146 The Commission chairman described its demise as "one of catastrophic failures of management, governance and regulatory oversight." 147 The Commission's final report, "Changing banking for good," begins by pointing out that

[t]oo many bankers, especially at the most senior levels, have operated in an environment with insufficient personal responsibility. Top bankers dodged accountability for failings on their watch by claiming ignorance or hiding behind collective decision-making. They then faced little realistic prospect of financial penalties or more serious sanctions commensurate with the severity of the failures with which they were associated. Individual incentives have not been

a crime to fail to comply with the duties imposed to manage risks if it "threatens the bank's viability as a going concern." Id., translated in Thomas Richter, The New German Ringfencing Act Establishing Criminal Liability of Banking and Insurance Executives for Failures in Rish Management: A Step Towards Corporate Criminal Liability?, in REgULATING CokPONATE CRIMINAL LIABILITY 321, 323 (Dominik Brodowski et al. eds, 2014). A significant limitation on liability requires that the official contravene a specific order issued by the Federal Financial Supervisory Authority (Bundesanstaltfïr Finanzdienstleistungsau/sichd) to remedy the company's failure to implement sufficient risk mechanisms. Richter, supra, at 323. Although the law targets senior management who put a financial institution at risk, the criminal penalty will apply only in very narrow circumstances in which an express administrative order is ignored. $I d$.

145 See Taxpayer Support for UK Banks: FAQs, U.K. NAT'L AUDIT OFFICE, http://www.nao.org.uk/highlights/taxpayer-support-for-uk-banks-faqs/ (last updated Mar. 31, 2013) (showing peak support for banks was $£ 1,162$ billion).

14 PARLIAMENTARY COMMISSION ON BANKING STANDARDS, 'AN ACCIDENT WAJTING TO HAPPEN': THE FaILURE OF HBOS, 2012-13, H.L. 144, H.C. 705 (U.K.), auailable at ht.tp://www.publications.parliament.uk/pa/jt201213/jtselect/jtpcbs/144/144.pdf.

147 Press Release, Parliamentary Comm'n on Banking Standards, Failure of HBOS Linked to "Colossal Faiture of Senior Management and the Board," Says Banking Commission (Apr. 5, 2013), available at http:/www.parliament.uk/business/ committees/committees-a-z/joint-select/professional-standards-in-the-bankingindustry/news/an-accident-waiting-to-happen-the-failure-of-hbos/. 
consistent with high collective standards, often the opposite. ${ }^{148}$

In its recommendations for reforming regulation of banks, the Commission suggested that Parliament enact "a new criminal offence of reckless misconduct in the management of a bank."149 The crime would be limited to senior bank officials, and they would be prosecuted in "cases involving only the most serious of failings, such as where a bank failed with substantial costs to the taxpayer, lasting consequences for the financial system, or serious harm to customers." 150 The report noted that there were a number of problems with using a lower standard for proving intent, such as strict liability or negligence, because, inter alia, it would be more difficult to attract talented individuals to work for a struggling bank and there would be a reasonable likelihood that courts would resist imposing a significant punishment for a conviction based on such a low level of personal fault.151 Thus, reckless conduct leading to significant economic harm is the Commission's suggested means for establishing criminal liability, with a recommendation that offenders face prison terms, potentially up to ten years, upon conviction. ${ }^{152}$

The British Treasury Department endorsed the recommendation for a new criminal offense for bankers, stating that it "will be a helpful deterrent against misconduct which can result in severe economic disruption and considerable losses for taxpayers." 153 'The focus is on deterrence: the possibility for

is Parlamentary Commission on Banking STANDARds, Changing Banking fol GOOD VOL. I, 2013-14, H.L. 27-I, H.C. 175-I, at 8 (U.K.), available at h.ttp//www-parliament.uk/documents/banking-commission/Banking-final-reportvolume-i.pdf.

149 Id. at 66 .

15 Id.

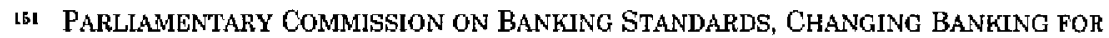
GOOD VOL. Il, 2013-14, H.L. 27-II, H.C. 175-II, at 513-14 (U.K.), quailable at http://www parliament.uk/documents/banking-commissian/Banking-final-report-volii.pdf.

162 Id. at $515-16$.

16\& HER MAJESTY's TrEASURY \& DEPARTMENT FOR BUSINESS INNOVATION AND Skills, The Government's Response to the Parlamentary Commission on BANKING STANDARUS, 2013, Cm. 8661, at 12 (U.K.), available at https:/www.gov.uk/government/uploads/system/uploads/attachment_data/file/211047/g ov_response_to_the_parliamentary_commission_on_banking_standards.pdf. 
criminal prosecution will lead senior banking officials to be less likely to adopt policies and undertake new efforts that put both the organization and the broader economy at risk. ${ }^{154}$

As adopted by Parliament in December 2013, the new criminal provision is narrow, applying only to senior management of a financial institution who make a decision, or fail to take steps to prevent a decision, that results in the failure of the bank. To prove a violation, the prosecutor must establish the following:

(b) at the time of the decision, [the person] is aware of a risk that the implementation of the decision may cause the failure of the group institution,

(c) in all the circumstances, [the person]'s conduct in relation to the taking of the decision falls far below what could reasonably be expected of a person in [that] position, and

(d) the implementation of the decision causes the failure of the group institution. ${ }^{155}$

The maximum punishment for a conviction upon an indictment is seven years in prison and a fine.156 The law incorporates the recklessness standard as the requisite intent for a violation. It includes a subjective element involving the defendant's awareness of the risk stemming from a particular decision, and the objective requirement that the conduct be "far below" what a reasonable person in a similar position would have

154 A rebuttable presumption was one proposed measure to reform banking practices in the United Kingdom and make enforcement more effective, by "[e]stablishing rules which would automatically ban senior executives and directors of failing banks from future positions of responsibility in financial services unless they could positively demonstrate that they were active in identifying, arguing against and seeking to rectify the causes of failure." See PARliAMEN'CARY COMMISSION ON BANKING STANDARDS, supra note 151, at 503-04. The rationale behind this approach was that it removes discretion from the regulator on whether to pursue an action, and overcomes much of the challenge of proving individual culpability. Another option considered was "reversing the burden of proof in cases where a significant failing has been identified." Id. at 506. This would require exceutives in a managerial role to show they have taken "all reasonable steps to avoid the failing concerned." $I d$. One problem with this approach, however, is that it comes close to imposing strict liability based on the losses caused, which could only be avoided if the executive could establish his or her reasonableness.

155 Banking Reform Act, 2013, c. 33, $\$ \$ 36(1)(\mathrm{b})$-(d) (U.K.).

156 Id. $\S 36(4)(\mathrm{b})$. 
done. 157 The offense is of limited application because it requires proof that the decision caused the financial institution to fail, which occurs when it is insolvent or subject to being taken over by the government due to its financial difficulties. 158

Bank executives would not be subject to prosecution for decisions that, though they did damage the enterprise, did not threaten the continuing existence of the financial institution. 159 The statute also refers to a "decision"160 in the singular, which means the prosecution would need to identify a particular corporate act, or perhaps a series of related acts, as the reason for the bank's failure. It is often difficult to identify any one act or failure as the "cause" of a company's demise, especially when it is a large organization subject to a number of different economic pressures. Therefore successfully prosecuting an executive for a bank's failure under this new provision may be inordinately difficult if the insolvency was the result of distinct reasons that combined to put it out of business. It may be a valid defense to argue that no single decision resulted in the failure or constituted recklessness standing alone, which may result in an acquittal, even if many separate actions combined to undermine the organization's viability.

In relying on deterrence as the justification for adopting this provision, Britain has enacted a law that could result in discouraging business decisions that could bring significant benefits to an organization if it turns out well. Thus, defining what constitutes a violation is crucial to this new law because, otherwise, it simply becomes a vehicle for post hoc discipline for decisions that turn out badly. Although Senator Elizabeth Warren said that "[b]anks should be boring,"161 any business requires some measure of risk if it is going to prosper, because not every loan is guaranteed to be repaid, nor is every loss from a transaction the result of faulty decision-making. This new crime

$167 \quad I d . \$ 36(1)(c)$.

15s Id. \& $37(9)$.

150 Id. \$36(1)(b).

$160 I d$.

161 See Jim Puzzanghera, Sen. Elizabeth Warren Starts Campaign to Force Banks to Be Boring, CHI. TriB. (July 12, 2013, 9:55 AM), http:/www.chicagotribune.com/ business/breaking/la-fi-mo-elizabeth-warren-banks-boring-glass-steagall-20130712story.html. 
may push bankers into adopting a more defensive approach to managing the business so that they can avoid any claim that they had acted improperly. That conservative approach may be an acceptable cost of preventing large-scale losses in the banking sector, because the policy, whether implicitly or explicitly, acknowledges that some financial institutions are so important that they are "too big to fail" and therefore significant risks need to be avoided. In that environment, a crime that allows for punishment of a bank officer who tests the government's resolve to preserve the financial system may be worthwhile. But if banks are expected to make profits from their activities, then taking fewer risks will result in lower returns, an outcome that may not be acceptable to investors, even if it works to protect the broader economy.

\section{CONSTRUCTING A NEW CRIME FOR CORPORATE MisCONDUCT}

The German abuse of trust offense and the British statute targeting bank mismanagement provide a framework for how a new law in the United States could be drafted to permit criminal prosecution of business decisions that result in a large-scale loss-a law that would not be an exercise in second-guessing. There are three points that the law would need to touch on to distinguish it from other provisions that have been used in the past against corporate executives, like the right of honest services theory of fraud: (1) the types of organizations subject to its proscription; (2) the intent level required to prove a violation; and (3) the type of conduct that will result in liability.

Regarding the potential scope of a new law, the British statute is narrower than the German abuse of trust provision or the right of honest services statute. Those laws are not limited to a single sector of the economy, and instead apply to any business organization in which there is a fiduciary duty imposed on officers and employees. Although banking is subject to significant federal oversight, the potential threat a business can pose to the broader economy is not limited to only those institutions with a bank charter. For example, insurance companies like AIG and investment banks like Lehman Brothers were at the heart of the financial crisis, but neither was regulated as a bank in 2008; nor are financial companies, even broadly defined, the only ones that 
can pose a threat of significant harm to the economy. The asset management industry in the United States, including pension funds and mutual funds, oversees trillions of dollars ${ }^{162}$ and can constitute just as much of a threat to the broader economy as a bank or brokerage firm. 'To target a new statute at a particular industry or economic sector could constrain the law too severely to be effective.

Moreover, if the statute is designed to provide a means to hold corporate officers responsible for decisions that inflict significant harm, then limiting it to a single industry might create a system in which some managers would be subject to liability while others in a similar position could avoid prosecution. The next financial crisis - when it comes-may be traceable to sectors far removed from Wall Street and global financial firms. The better approach to drafting a new law would be to focus on the means by which an improper corporate policy or managerial decision was implemented, without regard to whether the actor worked at a corporation holding a bank charter or a pension fund responsible for the financial health of thousands of workers and retirees.

On the issue of the proper level of intent for such an offense, the British Bank Commission makes a compelling argument that recklessness is a workable standard for imposing criminal liability. In the United States, the Model Penal Code defines this as a person who

consciously disregards a substantial and unjustifiable risk that the material element exists or will result from his conduct. The risk must be of such a nature and degree that, considering the nature and purpose of the actor's conduct and the circumstances known to him, its disregard involves a gross deviation from the standard of conduct that a lawabiding person would observe in the actor's situation. ${ }^{163}$

\footnotetext{
162 See Office of Fin. Researoh, U.S. Dep'T of the Treasury, Asset MANaGemENT and FINANCLAL StaBility 1 (2013), available at http:/www.treasury.gov/initiatives/ofr/research/Documents/OFR_AMFS_FINAT_.pdf ("The U.S. asset management industry oversees the allocation of approximately $\$ 53$ trillion in financial assets ...."

163 MODEL PENAL CODE $\$ 2.02(2)(c)(1985)$.
} 
Under this approach, not only must the person disregard the likely risks from a course of conduct, but that decision must constitute a "gross deviation" from what can be expected by a similarly situated executive. This goes beyond mere secondguessing of a business decision, something that a company is normally protected from by the Business Judgment Rule in corporate law. ${ }^{164}$ Instead, proving recklessness would require the prosecution to show that the decision was indefensible from a business standpoint, much like the corporate law doctrine of waste. This was essentially the standard used in the Mannesmann case involving a violation of Section 266.165 Thus, requiring proof of recklessness avoids imposing liability based only on the result of a decision without giving fair consideration to whether it was the product of a flawed process. Moreover, proof of recklessness could be established by the failure of corporate officials to see the potential for significant problems from a business decision due to the inadequacy of, or complete lack of, investigation into that possibility, much like conscious disregard of warning signs can be a way to prove knowledge. ${ }^{166}$

164 See In re Walt Disney Co. Derivative Litig., 731 A.2d 342, 362 (Del. Ch. 1998) (quoting Aronson v. Lewis, 473 A.2d 805, 815 (Del. 1984)) ("It is the essence of the businoss judgment rule that a court will not upply $20 / 20$ hindsight to second guess a board's decision, except 'in rare cases [where] a transaction may be so egregious on its face that board approval cannot meet the test of business judgment."'), aff'd in part, rev'd in part sub nom. Brehm v. Eisner, 746 A.2d 244 (Del. 2000).

เ65. See Gevurtz, supra noto 86, at 463-64.

th6 See supra note 25 and accompanying text; see also United States v. Carrillo, 435 F.3d 767, 780 (7th Cir. 2006) (explaining that "[i]t is appropriate to give the ostrich instruction where the defendant claims a lack of guilty knowledge, and the government presents circumstances from which a jury could conclude that the defendant deliherately avoided the truth"). Judge Posner once described vividly what the "ostrich instruction" is designed to permit a jury to find:

'The criticism can bo deflected by thinking carefully about just what it is that real ostriches do (or at least are popularly supposed to do). They do not just fail to follow through on their suspicions of bad things. They are not merely careless birds. They bury their heads in the sand so that they will not see or hear bad things. They deliberately avoid acquiring unpleasant knowledge. The ostrich instruction is designed for cases in which there is evidence that the defendant, knowing or strongly suspecting that he is involved in shady dealings, takes steps to make sure that he does not acquire full or exact knowledge of the nature and extent of those dealings. A deliberate effort to avoid guilty knowledge is all the guilty knowledge the law requires.

United States v. Giovannetti, 919 F.2d 1223, 1228 (7th Cir. 1990). 
Regarding the type of conduct that could constitute a violation, it is important to note that crimes usually involve some external manifestation of prohibited conduct and not merely an intent to engage in a violation. This component of the offense is commonly referred to as the actus reus element. The act requirement has been described by Professor Dressler as reflecting "three ingredients of a crime, which can be encapsulated in a single sentence: The actus reus of an offense consists of (1) a voluntary act; (2) that causes; (3) social harm."167 As an alternative to prohibiting a positive action, some criminal offenses premise liability on an omission: the failure to act when the person has a legal duty to engage in certain conduct to prevent harm. 168

To shape a new crime focused on corporate mismanagement, the starting point would be identifying a corporate policy or series of decisions that triggered the negative economic effect. The British statute requires that the decision cause the bank's failure, which sets a high bar to a successful prosecution, because in a complex business organization, ferreting out a single cause might be impossible. Causation is an element of a crime that is based on a result, but the corporate decision should not require proof that it was the sole cause of the loss. Instead, if prosecutors could identify a policy or decision as a significant contributing factor to precipitating the harm, then that should be sufficient to prove the crime.

For example, the recent civil enforcement action against JP Morgan Chase for trading through its London investment office might be the kind of conduct for which this standard could be applied to hold individual corporate officials liable. In a cease-and. desist order entered against the bank, issued after the corporation admitted to the violations, the SEC found that "senior management" failed to adequately respond to reports of significant losses that ultimately cost the bank over $\$ 6$ billion, because its internal controls were inadequate and officers did not provide the type of information necessary to permit the board of directors to

t67 JOSHUA DRESSLER, UNDERSTANDING CRIMINAL LAW 85 (5th ed. 2009).

lgs See, e.g., MODEL PElNAL CODE $\$ 2.01(3)(\mathrm{b})$ (1985) (stating that liability for an omission requires that "a duty to perform the omittod act is otherwise imposed by law"). 
respond appropriately. ${ }^{169}$ The order describes the conduct of a collective group comprised of JPMorgan's chief executive, chief accounting officer, and three other high-level managers as those responsible for the violations for both their actions and the failure to provide information. 170 Yet, only the bank was named in the proceeding, for which it paid a total of $\$ 920$ million in penalties to United States and British regulators. ${ }^{171}$ The conduct of the officers was clearly a violation of their obligations under the principles of corporate governance, resulting to some appreciable harm to the organization. Establishing individual liability for fraud would require proof of scienter, which means proving knowledge, or at least recklessness, for such a civil case. ${ }^{172} \mathrm{~A}$ criminal prosecution based on the recklessness of senior managers that damaged the bank would allow prosecutors to pursue cases similar to what is already the subject of SEC enforcement actions, and could be an important tool for situations in which the conduct by senior management is particularly harmful to the enterprise.

An interesting issue that arises in carving out a new offense is whether inaction alone could be sufficient to trigger liability, at least where there were sufficient indicators of potential significant harm to the enterprise and a failure to respond left the corporation susceptible to losses. This approach would involve an omission, which can fulfill the actus reus element of a crime so long as there exists a duty to act. State corporate law already imposes fiduciary duties on officers and directors to act in good faith and in the best interest of the organization by undertaking their roles with due care and to not engage in undisclosed self-

169 JPMorgan Chase \& Co., Exchange Act Release No. 70458, 2013 WL 5275772 (Sept. 19, 2013), available at http://www.sec.gov/litigation/admin/2013/34-70458.pdf.

$170 \mathrm{Id}$.

171 See Press Release, U.S. Sec. \& Exch. Comm'n, JPMorgan Chase Agrees to Pay $\$ 200$ Million and Admits Wrongdoing to Settle SEC Charges (Sept. 19, 2013), available at http//www.sec.gov/News/PressRelease/Detail/PressRelease/1370539819965. One can question the logic of imposing civil penalties on a bank for conduct that resulted in harm to the organization when it is the shareholders who bear both the impact of the violation and the cost of paying for the violation.

172 See, e.g., Ernst \& Ernst v. Hochfelder, 425 U.S. 185, 193 (1976) (stating that. scienter is a mental state embracing "intent to deceive, manipulate, or defraud"); Tellabs, Inc. v. Makor Issues \& Rights, Ltd., 551 U.S. 308, 319 n.3 (2007) ("Every Court of Appeals that has considered the issue has held that a plaintiff may meet the scienter requirement by showing that the defendant acted intentionally or recklessly, though the Circuits differ on the degree of recklessness required."). 
interested transactions. ${ }^{173}$ A new criminal provision could encompass both positive action and inaction in the face of clear danger signals, so long as either (or both) was undertaken recklessly.

The absence of criminal prosecutions from the financial crisis has been a reflection of the difficulty of proving a violation when $\dot{a}$ corporate officer gained nothing from the decision beyond otherwise permissible remuneration. In some cases, the executive may have suffered personal financial losses from the demise of a company when his or her shares became worthless as a result of a bankruptcy or government bailout. The actual gain realized by executives is not the best measure for assessing whether a decision has been so reckless that it should result in criminal liability, because of the significant harm inflicted on the economy and broader segments of society. Thus, the offense should be based on an assessment of both the recklessness of the decision-making process and the resultant harm caused by it, and should not be mitigated by any personal financial losses an executive may have suffered.

Statutes in Germany and Britain focus on the harm caused by the corporate official, unlike the Supreme Court's interpretation of $\$ 1346$ in Skilling, as requiring proof of an illicit gain from the breach of the duty to provide honest services. 174 Focusing in on harm inflicted would be a better means of policing corporate misconduct than looking primarily at the actor's personal gain; by extending the criminal proscription to conduct that falls outside the mail and wire fraud statutes, which already have proven effective when corporate officials misuse their position for personal gain, more misdeeds will be prosecutable.

What constitutes sufficient "harm" to permit a criminal prosecution may require a monetary threshold before a case can be initiated. It is often problematic to provide a dollar amount for measuring harm because almost any loss could have a significant

17. Emerald Partners v. Berlin, 787 A.2d 85, 90 (Del. 2001) ("The directors of Delaware corporations have a triad of primary fiduciary duties: due care, loyalty, and good faith. Those fiduciary responsibilities do not operate intermittently. Accordingly, the shareholders of a Delaware corporation are entitied to rely upon their board of directors to discharge each of their three primary fiduciary duties at all times.").

17 See supra note 137 and accompanying text. 
impact under particular circumstances. A widow living off a fixed pension or social security may be much more susceptible to harm than a sophisticated institutional investor who can endure a multi-million dollar decline in value. That said, the rationale of the British statute is that the law should only be used in egregious cases that result in a bank's failure. Although a bankruptcy requirement is too high a threshold, a significant monetary loss should be incorporated into the statute to avoid having any bad decision potentially subject to criminal punishment, which would cause managers to avoid most risks, even reasonable ones.

There is a provision of the federal criminal code that enhances the penalty for a "major fraud against the United States" if the value of the "grant, contract, subcontract, subsidy, loan, guarantee, insurance, or other form of Federal assistance, or any constituent part thereof, is $\$ 1,000,000$ or more."175 That provision was originally adopted in 1988 , when a million dollars was thought to be a considerable sum of money. Since then, there have been multi-billion dollar Ponzi schemes perpetrated by Bernie Madoff 176 and R. Alan Stanford, ${ }^{177}$ and even smaller ones with losses "only" in the hundreds of millions of dollars, like those conducted by lawyers Marc Dreier ${ }^{178}$ and Scott Rothstein. ${ }^{179}$ In the context of the financial crisis, using a low threshold for financial losses would make business decisions of almost any significance subject to potential criminal prosecution.

The new statute should address serious misconduct that causes widespread harm; so, if a monetary threshold for loss is to be used, it must be significant, perhaps even starting at $\$ 1$ billion in investor losses or costs imposed on the government (if it were required to protect workers and insurance funds, such as the Federal Deposit Insurance Fund or pension insurance funds, from flawed business decisions). That would ensure that only serious cases of executive malfeasance are potentially subject to prosecution, and would allow those working for smaller

\footnotetext{
17518 U.S.C. $\$ 1031$ (a) (2012).

120 See, e.g., In re Bernard L. Madoff Inv. Sec. LLC, 418 B.R. 75 (Bankr. S.D.N.Y.

177 See, e.g., Janvey v. Alguire, 647 F.3d 585 (5th Cir. 2011).

178 See, e.g., In re Dreier LL.P, 452 B.R. 391 (Bankr. S.D.N.Y. 2011).

17g See, e.g., In re Rothstein, Rosenfeldt, Adler, P.A., 717 F.3d 1205 (11th Cir. 2013).
} 2009). 
enterprises to undertake riskier decisions that would not have the same type of impact on the economy.

\section{CONCLUSION}

The public clamor for prosecutions-perhaps even show trialsof corporate executives for their decisions that helped trigger the financial crisis is difficult to ignore-something that former Secretary of the Treasury Timothy Geithner called "Old Testament justice."180 The demurrer of the Department of Justice due to the difficulty in proving intent for a criminal prosecution naturally raises the question whether the law should be modified to accommodate a lower standard to establish liability.

While it is certainly possible to draft legislation that broadens the criminal law to reach more corporate executives, the question remains whether it is a good idea. The financial crisis in 2008 was the worst since the Great Depression, and affected not just the United States but the global financial system as a whole. The interdependence of the world economy is not going to recede, thus a means to protect the system from the types of harm that can be inflicted by a few large banks, insurance companies, and investment firms is a reason to consider new laws and regulations to punish corporate misconduct.

A new means to reach individuals may avoid the problem of only having companies accused of wrongdoing while executives escape personal liability. Judge Jed S. Rakoff pointed to the move toward corporate criminal prosecutions, settled through deferred and non-prosecution agreements, as a reason why no senior executives were charged for wrongdoing in connection with the financial crisis, and argued for a return to individual prosecutions. ${ }^{181} \mathrm{He}$ asserted, "Although it is supposedly justified because it prevents future crimes, I suggest that the future deterrent value of successfully prosecuting individuals far outweighs the prophylactic benefits of imposing internal

180 Joshua Green, Inside Man, ATLanTIC (Mar. 9, 2010, 9:00 AM), http://www.theatlantic.com/magazine/archive/2010/04/inside-man/307992; see also Henning, supra note 15 , at 107.

18I See Rakoff, supra note 8. 
compliance measures that are often little more than windowdressing." 182

But whether the criminal law is the best means to prevent future misconduct by large institutions is less clear. In Dowling $v$. United States, ${ }^{183}$ the Supreme Court criticized the government's use of a broad theft statute to pursue a narrow copyright infringement, suggesting such an approach reflected "an indirect but blunderbuss solution to a problem treated with precision when considered directly." 184 Adding a statute to make it easier to prosecute executives when corporate decisions result in significant losses may well be a "blunderbuss solution" when the root issue is the size of financial institutions that creates the potential for one company to wreak significant havoc, much less an entire sector driving the economy to the brink of financial ruin. Does a new crime change that calculus even a little bit?

It may be that the financial crisis was sui generis, in that the combination of a residential real estate bubble fueled by lax standards for issuing subprime mortgages, mixed with mortgage securitization along with complex derivatives to spread risk throughout the financial system is not something that will be repeated. But then, corporate executives were called to account for misconduct in earlier times, like the savings and loan crisis; yet no one of any prominence in the banking and financial industry has been accused of a crime related to the decisions that led to the meltdown in the markets in 2008. Judge Rakoff noted the pernicious effect of this approach: "So you don't go after the companies, at least not criminally, because they are too big to jail; and you don't go after the individuals, because that would involve the kind of years-long investigations that you no longer have the experience or the resources to pursue." ${ }^{185}$ Even if a criminal law cannot prevent a future financial meltdown, it may add to the public's confidence that significant corporate malfeasance can be addressed at the individual level. Companies will happily pay monetary penalties, perceived as little more than a cost of doing business, effectively allowing executives to escape personal

\footnotetext{
182 Id.

183473 U.S. 207 (1985).

$184 I d$ at 226.

185 See Rakoff, supra note 8.
} 
accountability. A new law targeting corporate management for criminal prosecution may be a small step toward enhancing personal accountability for business decisions that lead to significant harm. 